\title{
The Use of Water Features in the Palace Landscapes of the Late Ottoman Era
}

\author{
Parısa GÖKER ${ }^{1^{*}}$ \\ 1: Bilecik Şeyh Edebali University, Arts and Design Faculty, Department of \\ Interior Architecture and Environmental Design, Bilecik \\ *: Corresponding Author, parisa.goker@bilecik.edu.tr
}

\begin{abstract}
Despite palaces reflect the cultural characteristics of their period they also reflect the life styles of people who lived in these sites and the artistic properties and construction techniques of the period. Garden culture has emerged as an outcome of human-nature relationships and changed and developed throughout history with the geographical, historical and socio-economic conditions of each period. Water features have always appeared as crucial design components in Turkish gardens. It is remarkable that fountains and dispensers, designed for meeting water utilization need, were also used for sound and cooling purposes. Water in Turkish gardens emerged as rich forms including dispensers, water pots and stagnant and running water. Pools were in the shapes of foursquare, rectangular or square starting from early Ottoman Period until the 18th century and subsequently, round and curvilinear-shaped pools took their place. Pool interiors were brightened by various means starting from the 18th century and for this purpose, islands, grotto made of artificial rocks, waterfalls and passages in the form of bridges were built in the middle. However, fountains and dispensers have been significant water features in every period. In this research, water features (pools, fountains, dispensers, waterfalls and grottos) situated in Yildiz Palace Gardens, erected as the final premises of the Ottoman Empire by Sultan II Abdulhamid and in Beylerbeyi Palace Gardens, constructed by Sultan Abdulaziz as a summer sea-side palace, will be scrutinized. Design and structural characteristics of water features that reached today and are situated in the palace gardens will be discussed based on the collected data and suggestions will be made for the current preservation issues.
\end{abstract}

Keywords: Palace gardens, Ottoman Era, Use of water 
İNÖNÜ ÜNIVERSITESİ SANAT VE TASARIM DERGISİ

Inönü University Journal of Art and Design

The Use of Water Features in the Palace Landscapes of the Late Ottoman Era

Extended Abstract

\section{Introduction}

Whereas historical gardens reflect the cultural features of their period, they also reflect the life styles of the people who use these places and the perspective of the period and construction techniques. Garden culture has emerged as an outcome of human-nature relationships, changed, and developed throughout history with the geographical, historical and socio-economic conditions of each period. Palaces functioned as the site of state administration and the Sultans' living area and reflected best the artistic and architectural cognizance of the period with its unique structures. Especially in the Ottoman palaces, composed of structure groups, the western influences were observed conspicuously starting from the $19^{\text {th }}$ century and as a result, unique designs and compositions were created (Erdoğan and Aliasghari, 2015).

The root of the word 'garden' is Persian and it means a 'small vineyard'. Generally, it is also defined as a land where herbaceous and woody decoration plants with certain visual qualities and fruits, vegetables and healing herbs are grown and where the beauty, green textural and relaxing characteristics of the nature are controlled by humans. Inward-looking gardens or backyards of small or large scale, integrated with the environment, reflect the living conditions and economic and cultural properties of the societies of a certain period of history and they are shaped in line with the characteristics of the region where they exist. In this context, the variances created by people and the diversity in garden arranging purpose have added numerous variations to the garden phenomenon emotionally and formalistically (Aliasghari and Erdoğan, 2012).

Gardens have been a type of shelter where people can recover from their problems caused by the redundancy of their daily lives and where they can mingle with the natural beings. On the other hand, in holly books and religious teachings, "heaven", the site where people shall be awarded and shall spend their second lives is defined as an extremely attractive garden.

The water features in Turkish gardens have a substantially rich quality. In addition to very plain water components in Turkish gardens including pools, fountains, etc., the water use encompassing a wide range including waterfalls which consist of the most complex solutions has been predicated as a unique solution. There are always pools and sprinklers in gardens and they are connected with each other by means of water lines in the form of canals embedded in the marble ground. Fountains and water dispensers have been crucial water features in every period.

Pools had four corners and were rectangular or square during the Ottoman Empire period until the $18^{\text {th }}$ century and subsequently they were replaced with mostly round and curved pools. Pool interiors were brightened by various means starting from the $18^{\text {th }}$ century and for this purpose, islands and sprinklers, waterfalls and passages in the form of bridge that were made of artificial rocks were built in their center (Atalay Seçen, 2011).

\section{Material and Method}

In this research, the use of water features in the palace landscapes of the late Ottoman era was assessed. In this context, the water features (pools, fountains, dispensers, waterfalls and grottos) situated in Yildiz Palace Gardens, erected as the last premises of the Ottoman Empire by Sultan II Abdulhamid and in Beylerbeyi Palace Gardens, constructed by Sultan Abdulaziz as a summer sea-side palace, were scrutinized. The main material of the research included Beylerbeyi Palace Gardens, Yildiz Palace Gardens and the surveys prepared by the Grand National Assembly of Turkey, Department of National Palaces on the issue and palace archives and published and visual materials on the issue. Based on these data, the water features used in Beylerbeyi Palace gardens and Yildiz Palace gardens of late Ottoman era were scrutinized. The research data were analyzed systematically and assessed and synthesized.

\section{Results and Discussion}

It was seen that stagnant water was not used in traditional Turkish gardens and water movement was facilitated generally. Despite the pools had corners it was seen that round 
pools were used in the $18^{\text {th }}$ century and artificial lakes were used in the $19^{\text {th }}$ century, although very scarcely. Orderly stones or pathways with marble pavement generally surrounded poolside's. Pool peripheral walls were made of bricks mostly, their depth was not more than $1-1,5 \mathrm{~m}$, and it was approximately half a meter in small tubs. The grounds were plastered by grog. On the other hand, there were marbles surfaces where water washed the curbs. Canals were used to create water tricks generally. Interconnected pools were encountered more often starting from the $18^{\text {th }}$ century. Pools of modest sizes were used in house gardens. In time, the number of sprinklers used in especially palace gardens increased as the pools enlarged. Despite the sprinklers were situated in the center generally they were also used in four corners at times. 
The Use of Water Features in the Palace Landscapes of the Late Ottoman Era

\section{Beylerbeyi Palace Gardens}

It has been a long time since the use of the area where Beylerbeyi Palace is located in Uskudar County in the Anatolian side of Bosphorus as a residential area. This area used to be known as Arhai Foisuai and referred to as Istavroz Gardens during the Byzantine Period. Sultan II. Mahmud built Old Beylerbeyi Palace in the place of Beylerbeyi Palace of today during 18261832. Abdulaziz demolished this Palace and during 1863-1865 built New Beylerbeyi Palace which has lived until today. New Beylerbeyi Palace was built during the Ottoman Empire modernization period. Beylerbeyi Palace was built differently from Dolmabahce and Ciragan palaces which were built in the 19th century and was used generally to accommodate representatives and foreign guests. Moreover, this palace functioned as a summer shore palace for the emperor and his family especially during spring months. It is known that Sultan Abdulmecit who succeeded to the crown after II.Mahmud used the Old Beylerbeyi Palace as a summer palace. However, Sultan Abdulmecit moved to Ciragan Palace because of a fire that took place in 1851 . The palace was not used for a certain period, and demolished later on and Architect Sarkis Balyan built Beylerbeyi Palace that is existing today.

New Beylerbeyi Palace was erected in the 19th century, during the modernization period of Ottoman Empire open to western in-

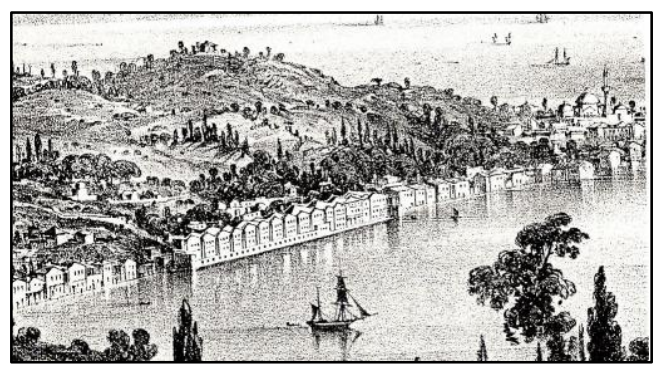

Figure 1. Old Beylerbeyi Palace Gardens (Batur, 1994)

\section{Fountains in Beylerbeyi Palace Gar- dens}

The word fountain, originating from the word 'çeşm' in Persian, means water fluences. New Beylerbeyi Palace was generally used to accommodate representatives and foreign state guests. In addition, the emperor and his family used the place as a summer seashore palace during especially summer months. Based on the first construction books of July 1863, construction of Beylerbeyi Palace was completed in 1863-1865 and Sultan Abdulaziz moved to the palace and it was officially opened on April 25, 1865 following a Friday prayer (Dundar, 2008).

Old Beylerbeyi Palace was demolished after the 1851 fire. Sultan Abdulaziz had the current Beylerbeyi Palace erected during 1861-1864. Based on the information gathered from the Ottoman archives, New Beylerbeyi Palace was designed and built by Sarkis Balyan, whose title was mentioned as Mabeyn-i Hümayun Chief Architect and later on mentioned as Sermimar-I Devlet, and his brother Hassa Architect Agop Balyan. Current Beylerbeyi Palace is a palace complex consisting of a shore palace and structures and mansions connected to it. When generally inspected, it is clear that all units of the palace are arranged on the land as independent from each other. Main structure of the palace is located on shore and other sections are dispersed in set gardens. Sari Mansion and Mermer Mansion are located in the upper section around the large pool, Ahir Mansion, on the other hand, is situated in the back part of the land.

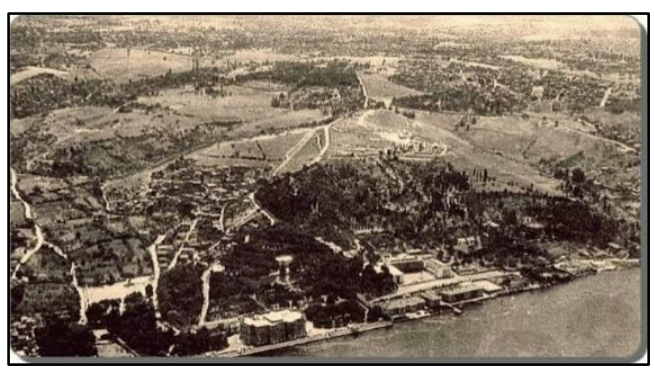

Figure 2. New Beylerbeyi Palace Gardens (Aliasghari, 2016)

discharging structures. The pipes (lüle) enabling constant water flow in fountains 
were replaced by faucets preventing water waste. The pipes or faucets were placed on a base called the mirror stone. In some fountains, there were bowl alcoves at the sides or upper part of the faucets for the placement of bowls used for water drinking. The fountain alcoves separated the section containing the faucets from the other parts in the facet design. There were mirror stones containing tablets, faucet mirrors and faucets in the area designated as an alcove by using arches. In fountains, the area where the water flowing through the faucets accumulated was called the tub, tank or basin. The fountains and water dispensers reflected the culture gusto and architectural properties of their construction period.

There were two fountains in Beylerbeyi Palace gardens. One of these fountains situated on the exterior garden wall of the Palace facing Gumusyol. The other fountain was placed within the tunnel. The fountain tablet verses were written by the poet Hilmi. The writings on the tablet were written by the renowned calligrapher of the period Yesarizade Mustafa Izzet.

The inscriptions on the tablet of the fountain erected by Sultan II Mahmud in 1829;

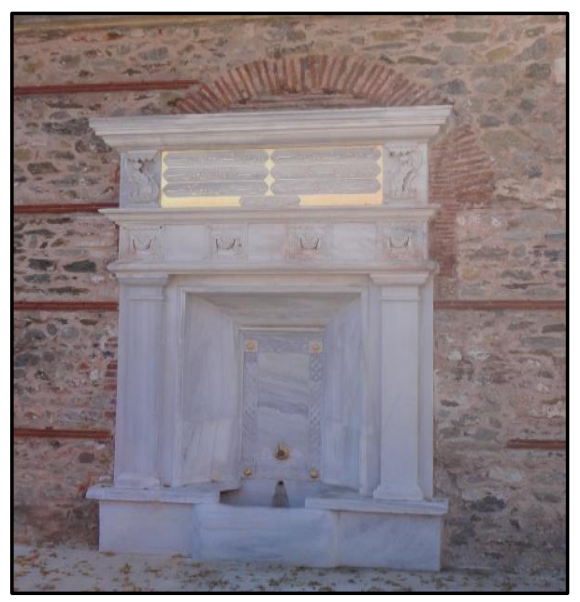

Figure 3. The fountain situated on the exterior garden wall of Beylerbeyi Palace (Original, 2013)

\section{The Pools in Beylerbeyi Palace Gardens}

The other water features in Beylerbeyi Palace gardens were the pools. These pools
Ab-ı ruy-ı Saltanat Hajan-ı Mahmudu'ş -şeym

Yapdı bu nev çeşme-i zemzem nihad-ı atharı

Besmeleyle nuş eden ab-ı şifa bahşasını

Ömrü ley oldukça olur enva-ı illetden beri

Hilmiya tarihini cevherle tahrir eyledim Han Mahmud eyledi icra bu ayn-ı kevseri

The inscriptions on the tablet of the fountain erected by Sultan II Mahmud in 1829;

Padişah-ı pür himem Sultan Mahmudül hisal

Yapdı ziba çeşme-i dilcu ter-i lezzt resan

Menbaı Firdevs-i a'lamdar misal'i selsebil

Cüz-i iksir hayat olmuş mizacında cihan Gevher-i tarih-i mervidir Hızır'dan Hilmiya

Cedvel-i ab-ı hayatı kıldı Mahmud Han revan

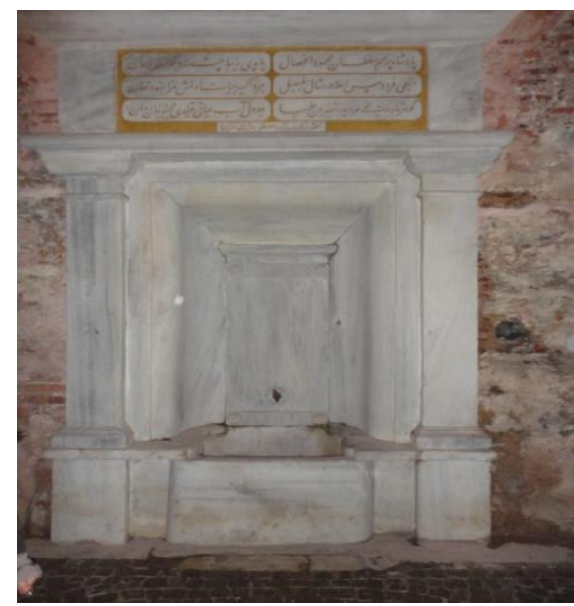

Figure 4. The fountain situated within a tunnel in Beylerbeyi Palace (Original, 2013).

were built in 1863 during the construction of New Beylerbeyi Palace gardens. The 


\section{INNÖNÜ ÜNIVERSİTESI SANAT VE TASARIM DERGISİ İnönü University Journal of Art and Design}

The Use of Water Features in the Palace Landscapes of the Late Ottoman Era

pool of an oval shape having a grotto and making up the central axis and situated in the portion of the palace reserved for selamlik and in harem was remarkable. The designs of the pools in the gardens of the portion reserved for selamlik and harem were similar. The size of these oval-

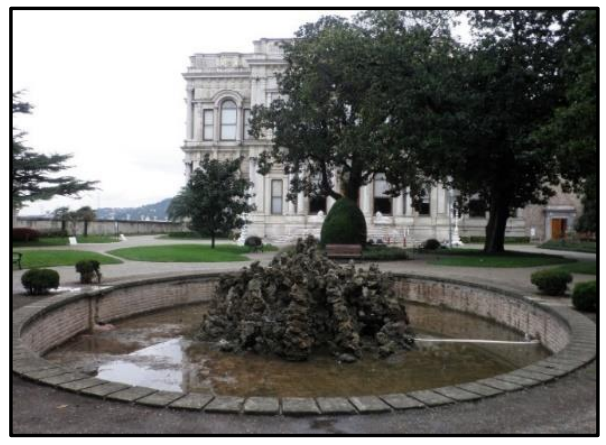

shaped pools surrounded by limestones was approximately 15 meters. There was a grotto in the middle of the pools. The roundshaped pool situated in the first set was surrounded by limestones and there was a grotto in the middle.

Figure 5. Selamlık and Harem Garden Pools

Another characteristic making Beylerbeyi Palace gardens unique was the Big Pool situated in front of Sari and Mermer mansions in the fourth set. This pool was built
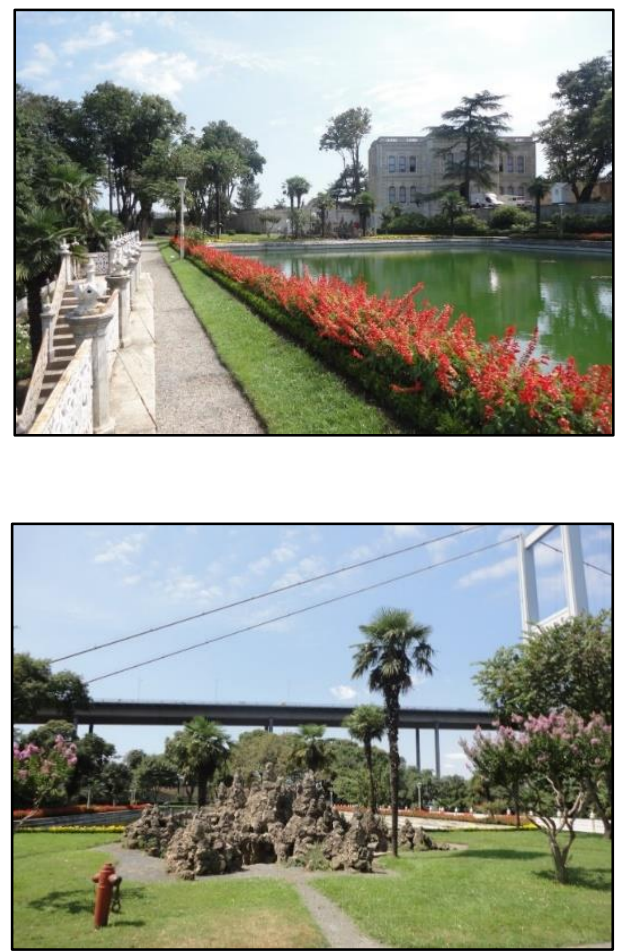

during Mahmud II era and its dimensions were $80 \times 30$ meters and its depth was 3 meters. There were artificial grottos at both sides of the Big Pool.
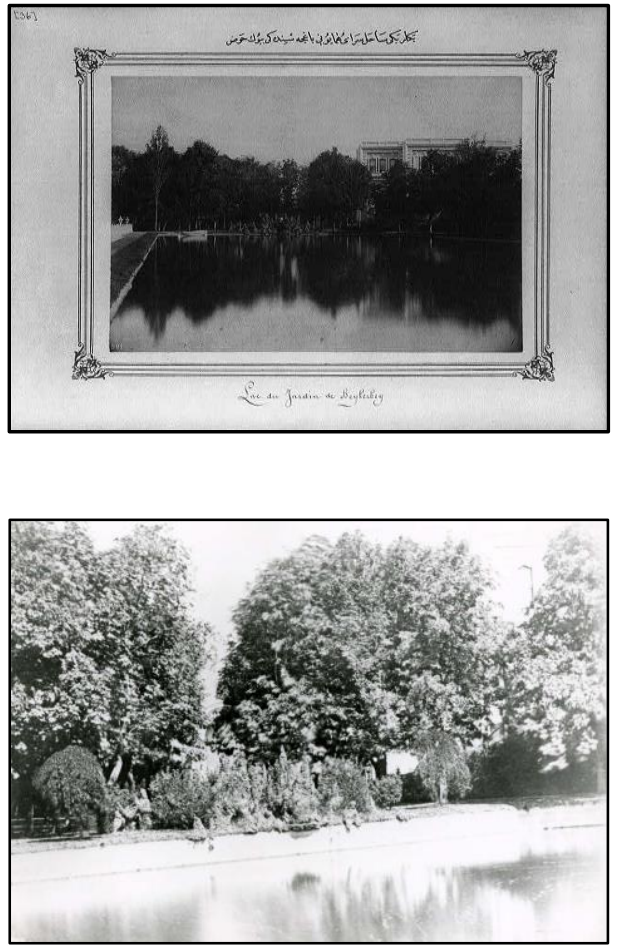

Figure 6. A photograph taken by Basile Kargopoulo in 1880, the Library of Congress 


\section{Yildiz Palace Gardens}

Yildiz Palace was the last palace compound of the Ottoman Empire covering an approximately $500,000 \mathrm{~m}^{2}$ of area on a hill in Besiktas County dominating the Bosporus and on a brow between Besiktas and Ortakoy. This Palace started at the shore between Besiktas and Ortakoy and covered the entire brow until Besiktas Hill and was a palace complex consisting of mansions, administrative structures and parks within a garden and coppice.

The history of the region goes back to the Byzantium Period and it is known that there was a large forestland during that period. Yildiz region maintained its forest characteristic during the Ottoman Era as well and it was used as a recreation area of the Sultans starting from Suleiman the Magnificent era (1520-1566). The region kept this characteristic for a long time after the conquest of Istanbul and was known as Kazancioglu gardens as well during that period. It

Selim III fountain, the oldest known structure in Yildiz Palace, was built by Selim III for his father Mustafa III in 1805. This fountain of the rococo style had four facades and the base of it was marble and its roof was plated with lead over wood. The roof consisted of a large dome in the middle and four bulbous domes at the corners. There were ornaments under the eaves and Sultan III Selim's signature situated on its four became one of the private gardens of the Sultan during Ahmet I era (Niğdeli, 2005). Sultan Ahmet I erected a small mansion for his daughter Kaya Sultan in this area called Besiktas Hill as well. An important structure reaching today from that era was the fountain built by Selim III for his father Mustafa III. It was preserved as a forestland with its natural vegetation without any change as a back coppice of Ciragan Palace until the first years of the $19^{\text {th }}$ century. The mansion, which was built by Selim III (1789-1807) for his mother Mihrisah Valide Sultan at the beginning of the $19^{\text {th }}$ century and does not exist today, was one of the first known structures. In addition, the fountain built by Sultan III for himself was the oldest structure reached today since it was situated in an interior garden (Kaşif, 2010). Mahmud II called the mansion built during 1808-1839 'Yildiz' and the Palace and the entire region have been called Yildiz since that era till today.

sides. There was a tablet inscribed with gilded letters as phrases following one another inside the oval medallions on the four sides of the fountain and its corners were defined with embedded columns. The tiling around the fountain was built of marble. There were marble pots at the corners of the tiling as shown in the old photographs (Aliasghari, 2016).

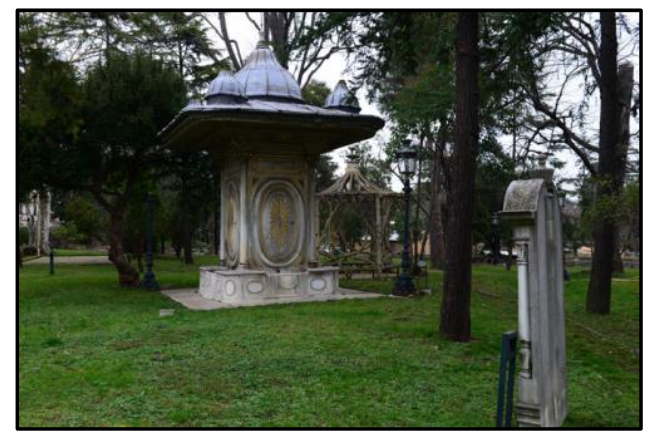

Figure 7. The fountain built by Sultan Selim III, The current state of the fountain built by Sultan Selim III (Niğdeli, 2005)

It was preserved as a forestland with its natural vegetation without any change as a back coppice of Ciragan Palace until the first years of the $19^{\text {th }}$ century. The mansion, which was built by
Selim III (1789-1807) for his mother Mihrisah Valide Sultan at the beginning of the $19^{\text {th }}$ century and not existing today was one of the first structures. In addition, the fountain, which was built by Selim III for himself, 


\section{INÖNÜ ÜNIVERSITTESI SANAT VE TASARIM DERGISİ \\ İnönü University Journal of Art and Design}

\section{The Use of Water Features in the Palace Landscapes of the Late Ottoman Era}

was the oldest structure that reached today because it was situated in an interior garden (Kaşif, 2010).

One of the most important water structures in the garden was the fountain designed by period. All fountains built during the Ottoman era had a functional purpose primarily and they gained aesthetic characteristics subsequently. However, the fountain designed by Raimonda D'Aronco had a visual purpose. In addition to the fountain designed by D'Aronco, there were two other fountains in the first yard. Despite there were no conclusive information acquired about these two fountains, the fountain situated at the entry of the Large Chamber building was dated back to 1843 and under this condition, it was designated that this architecture Raimonda D'Aronco and situated at the southwest of Cit Pavilion. This fountain was the first sample pouring water in stages until that

fountain belonged to Abdulaziz era. Hamidiye Fountain leaning on the wall of $\mathrm{Ya}$ veran Suite was dated back to 1903 . However, there was no detailed information on its construction. There were two more fountains in the yard. Among these fountains, the one situated at the entry of the Large Chamber belonging to Abdulaziz era was built in 1843. It is thought that the fountain situated at the entry of the second yard was designed by D'Aronco however it was moved to its present location from another place (Altıner 2008). There was no information found about the other fountain.
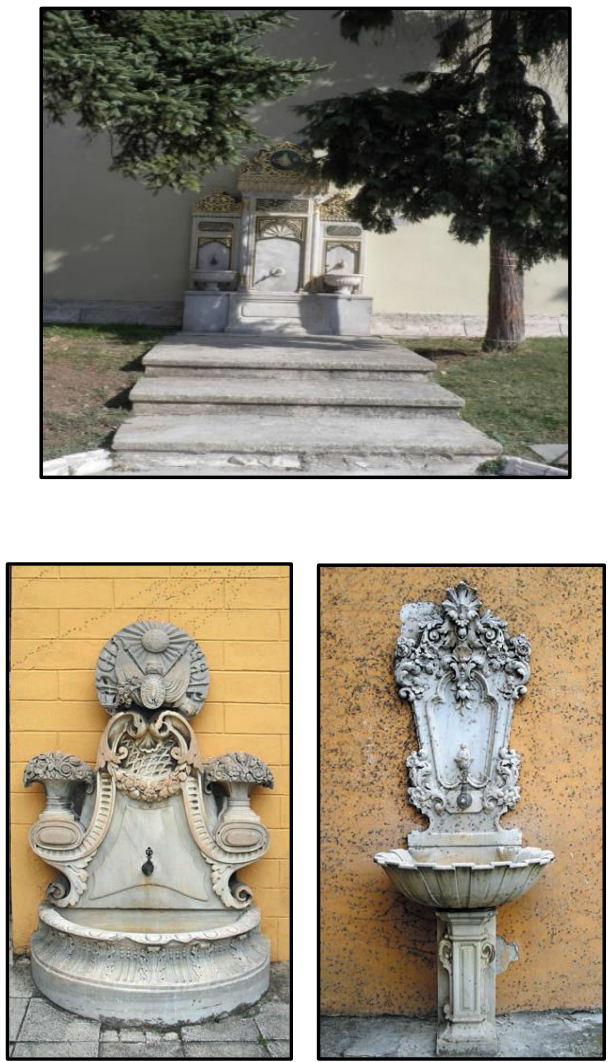

Figure 8. The first yard, the fountain designed in 1984, (Original, 2012).

Figure 9. The first yard, the fountain built in 1943, (Original, 2012).

Figure 10. Harem Garden, the fountain built in 1896-1896, (Uğuryol, 2011). 
It is known that Abdulhamid II started to form the garden and pool before he erected his private suite. The centerpiece of the private garden was Hamid Pool of a 300 meter of length with a river appearance. The surface area of this pool was approximately 5400 square meters and its depth was 120 square meters. Hamid Pool was designed in the shape of a river and extended from one end of the garden until its other end. Hence, an island was generated surrounded by the pool at the south of the garden (Evyapan, 1972). The connection with this island was ensured by an iron construction swing bridge and a flat, wooden bridge. This steel bridge was able to be opened and closed by means of a lever when necessary and the animals living in cages were let free on the island. The "private garden' surrounded by high walls was erected for the use by the Sultan and his next of kin during Sultan Abdulhamid II Era. The private garden was assessed as the interior garden of the palace and reflected the 'natural' English garden style's designing features.

The 'private garden', the extension of the first and second yards, was surrounded by high walls. There was an elevation difference of 12-13 meters between the northern and southern portions of the private garden field (Kaşif, 2010). The centerpiece in the main set of the garden was 'Hamidiye'

\section{Conclusion}

The western influence on the OttomanTurkish gardens started to be seen during the 'Tulip Era'. Despite the limitations in this era, which was the start of administrative and political recession, it was a crucial period for fine arts and landscaping. Istanbul has gained a 'garden and water city' look due to numerous beach-palaces, mansions and villas and coppices built by primarily Ahmet III and state figures and wealthy people and extending from $\mathrm{Ka}$ githane Valley till the shores of the Bosporus and Straits. During this era, whereas mere Turkish garden features, i.e., an informal mingling with the nature, and the formalism approach not overstepping the con-
Pool, which had a 300 meter of length and was an artificial pool built for touring (Niğdeli, 2005). The components and structures used for creating a natural look in the garden were a natural looking artificial island in the pool, an island mansion situated on this island, the bridges situated at the narrowing portion of the pool, grottos and cascaded used at the connection places of the bridges with the land and the waterfalls generated for facilitating water movement.

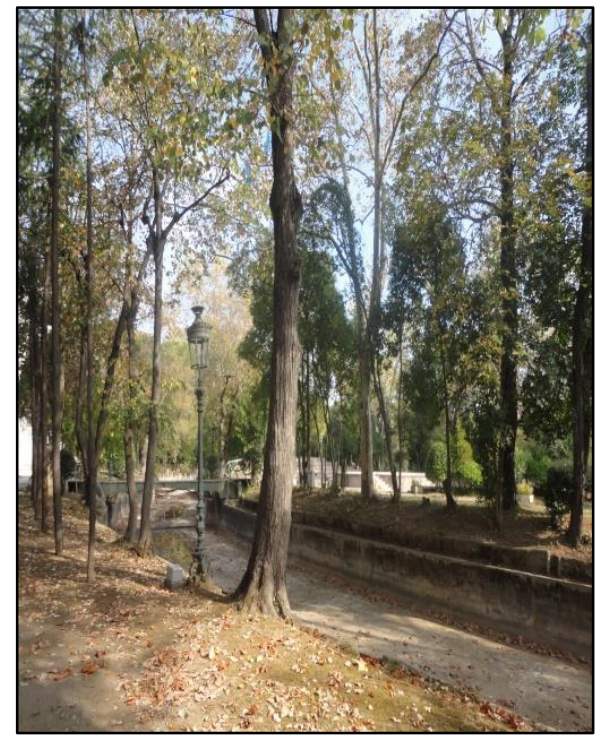

Figure 10. The private garden, Hamidiye Pool (Original, 2012)

trolled use manner of garden features existed in small-scale gardens, the western influence started to appear gradually in large-scale gardens of the state figures. Whereas, the Renaissance and Baroque garden phenomena were replaced by English naturalist gardens in Europe, Turkish gardens gained a different identity by the western influence.

The best examples of the palace landscapes designed under the western influence are the gardens of Beylerbeyi Palace, Ciragan Palace and Dolmabahce Palace erected in Istanbul during the $19^{\text {th }}$ century. Water had been an indispensable feature in these gardens. The movement of pool 
İNÖNÜ ÜNIVERSITESI SANAT VE TASARIM DERGISİ

İnönü University Journal of Art and Design

The Use of Water Features in the Palace Landscapes of the Late Ottoman Era

water was facilitated by sprinklers and waterfalls, and islands, bridges and reefs were built over them and boats were floated. Whereas the pools were built in a rectangular at the beginning, they were round, oval, undulated in the 18th century, and turned to artificial lakes during the $19^{\text {th }}$ century. All gardens consisted of fountains, water dispensers and water-tanks. Pools, sprinklers and water channels were also used commonly in Istanbul gardens, the most important recreation spots throughout history.

Beylerbeyi Palace gardens and Yildiz Palace gardens, investigated in the scope of this study, are significant both today and for the future generations since they are cultural heritages. Furthermore, due to their significant cultural, recreational and touristic functions of historical palace gardens in daily use, the quality and quantity and structuring of their vegetation during various eras and being subject to the influence of different art movements have improved the significance of such formations.

With the start of the Tulip Era (1703-1730) following the classic Ottoman Era, the gardens which had plain design lines were replaced by the designs reflecting the western influence. Tall trees featuring the plain and simple design characteristics of the classic era, flower stalls situated under the trees, simple and unornamented marble fountains and square or rectangular pools under tall trees generating shadows in the center of yards were replaced by sectional or round pools ornamented with various bird figures and pools with grottos starting from the second half of the $19^{\text {th }}$ century and cascade wall fountains reflecting the western influence started to be designed.

Pools were one of the remarkable structural features in palace landscaping in the study scope. Pools were components that took place sometimes with sprinklers, cascades, grottos and waterfalls and emerged as the leader of the movement they reflected. The other structural components related with the water use in gardens were the fountains. We encountered the fountains engraved with the art details of the era sometimes as single uses in garden interiors and sometimes as their uses on garden walls. The fountains softened the large and high effects of the walls in this use and reflected the functionality feature of landscaping as well.

Yildiz Palace gardens had characteristics differing from the other palaces and gardens structurally and in terms of location. Moreover, they had a sectional order showing the western influences more conspicuously due to their construction in the late Ottoman era. Whereas garden structures and mansions had Turkish garden characteristics in terms of the used water features, vegetative design approaches and yard uses, they showed the western influences in the scope of open-green area set up, spatial uses and equipment however they were an Anatolian synthesis in terms of living culture.

Beylerbeyi Palace gardens reflected the western influences distinctly in terms of both their structural design and garden lines and vegetative design among the other palace gardens that managed to reach today. It was seen that the entire structures of the palace were positioned independently and unsymmetrically. The main structure of the palace was positioned at the seafront and the other structures were dispersed in the set gardens based on their function. Comparing Beylerbeyi Palace gardens with the other palace gardens in terms of their general design characteristics they had a different set up in terms of both their mansion structures positioned at the seafront and garden relationships and terrace gardens. Whereas the gardens situated between the palace complex (the main structure) and the sea were designed as to have a more general use and in a formal order, the terrace gardens situated at the upper elevation were designed for more special uses. A portion of the terrace gardens had a geometrical stall arrangement and the terraces situated at the upper elevation had a more informal arrangement.

Whereas the architectural design characteristics of the palace gardens, façade designs and the formal order dominating the garden and oval pools with grottos and the used animal figures positioned in this formal order reflected the western influence, and the fountains situated at the palace entry had Turkish garden characteristics. 


\section{BIBLIOGRAPHY}

Aliasghari Khabbazi, P. ve Erdoğan, E. (2012). İslam Bahçeleri. Journal of Tekirdağ Agriculture Faculty, 9(2), 20-31.

Aliasghari Khabbazi, P. ve Erdoğan, E. (2015). Tarihsel süreç içinde Beylerbeyi Sarayı bahçelerinin gelişiminin irdelenmesi. First National Landscape Architecture Congress, 1517 October 2015. Ankara Üniversitesi Publications, Ankara, 37-48.

Aliasghari Khabbazi, P. (2016). İstanbul, Beylerbeyi sarayı Bahçeleri tasarım Illkeleri ve Restitüsyonu. PhD Thesis. Ankara University, Ankara, 260-400.

Altıner, F. (2008). II Abdülhamid Dönemi'nde Istanbul Bahçeleri. Master Thesis. Yildiz Teknik University, İstanbul, 25-100.

Atalay Seçen, E. (2011). Dolmabahçe Sarayı ve Bayıldım Bahçeleri 19. yüzyıl tasarım ilkeleri ve restitüsyonu. PhD Thesis. Ankara University, Ankara, 56-150

Batur, A. (1995). Dolmabahçe Camii. Dünden
Bugüne Beşiktaş Ansiklopedisi, 3, Kültür Bakanlığı ve Tarih Vakfı Publications, İstanbul.

Dündar, M. (2008). Beylerbeyi palace. PhD Thesis. Ankara University, Ankara, 180-235

Evyapan, G.A. (1972). Eski Türk bahçeleri ve özellikle eski Istanbul bahçeleri. Middle East Technical University, Faculty of Architecture, Publication No:20. Ankara, 164.

Kâşif, B. (2010). Osmanlı saraylarında Dış Mekân Tasarımı Üzerine Bir Değerlendirme; Dolmabahçe ve Yıldız Sarayı Örneği. Master thesis. İstanbul Culture University, Department of Interior Architecture and Environmental Design, İstanbul, 176-266.

Niğdeli, E. (2005). Yıldız Teknik Üniversitesi Mimarlık Fakültesi (Yıldız Sarayı Damatlar Dairesi) Binasının Mimari Değerlendirmesi ve Koruma Sorunları. Master Thesis. Yıldız Teknik University, İstanbul,128-255. 